\title{
CORRECTION
}

\section{Correction to: Outness Profiles and Mental Health in Brazilian Lesbian Women: a Cluster Analysis}

\author{
Aline Pompeu Silveira ${ }^{1} \cdot$ Elder Cerqueira-Santos ${ }^{2} \cdot$ Aline Nogueira de Lira $^{3}$
}

Published online: 23 November 2021

๑) Springer Science+Business Media, LLC, part of Springer Nature 2021

Correction to: Sexuality Research and Social Policy https://doi.org/10.1007/s13178-021-00663-x

The original version of this article unfortunately contained a mistake. The name of Elder Cerqueira-Santos is now corrected in the author group.

The original article has been corrected.

Publisher's Note Springer Nature remains neutral with regard to jurisdictional claims in published maps and institutional affiliations.

The online version of the original article can be found at https:// doi.org/10.1007/s13178-021-00663-x.

\section{Aline Pompeu Silveira}

1 Programa de Pós-Graduação em Psicologia, Universidade Federal de Sergipe, São Cristóvão, Brazil

2 Departamento de Psicologia, Universidade Federal de Sergipe, São Cristóvão, Brazil

3 Universidade de Fortaleza, Fortaleza, Brazil 